| Volume-1 | Issue-1| Jun-Jul -2019 |

Original Research Article

\title{
Establishment of Organizational Culture to Support Innovative Public Sector Performance
}

\author{
Ihyani Malik ${ }^{1 *}$, Zulfan Nahruddin $^{2}$ \\ 1Public Administration, Muhammadiyah University of Makassar, Kota Makassar, Sulawesi Selatan 90221, Indonesia \\ ${ }^{2}$ Government Science, Muhammadiyah University of Makassar, Kota Makassar, Sulawesi Selatan 90221, Indonesia
}

\section{${ }^{*}$ Corresponding Author}

Ihyani Malik

\author{
Article History \\ Received: 26.06 .2019 \\ Accepted: 14.07 .2019 \\ Published: 30.07 .2019
}

\begin{abstract}
This study aims to examine the Establishment of Organizational Culture to Support Innovative Public Sector Performance in the state civil service apparatus in Makassar City. This study uses a qualitative approach with descriptive research types. This research is located at the SKPD level in Makassar City, by collecting data through interviews and observations and the data analyzed by stages of data reduction, data presentation, and conclusion drawing. The results of the study show that the work environment requires work discipline and regular time so that it distinguishes from a flexible work situation in a number of new employee workplaces. Indonesia is very important to understand ASN especially in understanding integrity pacts. Exemplary which is first owned by the head of the organization in order to transmit the spirit of his example to all employees within his institution. The ceremonies related to development are shown through the Development Planning Consultation as a means to involve the community in regional development planning. The problem found was the lack of communication between institutions which resulted in the obstruction of the government's strategic program so that network development needed to be improved in terms of communication.
\end{abstract}

Keywords: organizational culture, public sector, innovative

\section{INTRODUCTION}

The organization is a social unit of society that is systematic, structured and managed to meet needs or in other words to achieve the shared goals set by the organization on an ongoing basis. The existence of an organization is influenced by a number of aspects including the unification of the organization's vision and mission to carry out organizational goals [1]. One measure to determine whether the organization is a good organization is if the organization is recognized by the community.

The core component of an organization that is successful in achieving its objectives is not only from qualified human resources, but organizations that are able to create and shape the resources contained therein are able to move productively in achieving organizational goals [2]. For that we need a management process to direct the organization in accordance with the direction and objectives of the organization that has beenset.

The success of the organization in achieving its objectives is largely determined by external and internal factors of the organization. External factors are anything that is outside the organization, but has a large influence on the organization [3]. As for the internal factors of the organization besides being supported by the resources needed to realize organizational goals, the very big role is the organizational culture adopted by all human resources in the organization [4].

Culture that exists in the organization can determine the success of an organization, whatever the form and purpose of the organization. Work culture is also considered to influence the relationship and work atmosphere towards a better one, and is able to influence work outcomes and satisfaction better [5]. Changes in internal and external conditions that are difficult to predict require the existence of creative, innovative and competitive human resources [6].

In government agencies if there is no creativity and innovation the organization will be less developed and its performance will always be in the public spotlight, criticism given by regional parliamentarians based on community complaints [7]. Therefore,

Copyright @ 2019: This is an open-access article distributed under the terms of the Creative Commons Attribution license which permits unrestricted use, distribution, and reproduction in any medium for non commercial use (NonCommercial, or CC-BY-NC) provided the original author and source are credited. 
creativity and innovation in every government institution that wants to advance must strengthen it internally first, thus when internally it is strong and produces innovative government programs, it will automatically be controlled when facing external problems. This study examines the Establishment of Organizational Culture to Support Innovative Public Sector Performance in the state civil service apparatus in Makassar City.

\section{METHODOLOGY}

This study uses a qualitative approach with the type of descriptive research used to describe the formation of an Organizational Culture to Support innovative Public Sector Performance. This research is located at the SKPD level in Makassar City, by collecting data through interviews and observations. The informant collection technique used is Purposive sampling of people who are able to provide information about the situation and background conditions of the research related to the formation of an Organizational Culture to Support innovative Public Sector Performance. Activities in data analysis, namely data reduction, data display, and conclusion.

\section{RESULTS AND DISCUSSION}

The focus of this research is; establishment of an Organizational Culture to Support innovative Public Sector Performance in Makassar City. The description of the focus refers to indicators: the environment, defined as the environment in which the organization operates will determine what must be done to achieve success, values (values) namely the basic concepts and beliefs of the organization, role models / example, which is meant by people who become role models or role models for other organizations because of their success. Ceremonies (rites and ritual); routine events held by the mayor's leadership or SKPD leadership, Network, which is an informal communication network within the scope of the SKPD leadership that can be a means of disseminating values from organizational culture.

\section{Environment}

The consequence of being a state civil apparatus is to pursue a career truly from the bottom even though graduates are because they do not know the real work environment. Knowledge gained from lectures lacks relevance to the work situation of state civil apparatus especially the work culture that exists within government organizations.

Based on the results of interviews, new employees need time to control the situation and conditions of the work environment. Therefore adaptability must be done as soon as possible, especially the knowledge and theory that is accepted while still in college need to be supported by training so that new employees can immediately adapt well.

The opinions conveyed must pay attention to the bureaucratic ethics carried out politely and keep the situation conducive in a forum attended by seniors who have long been ASNs. The more senior experience of ASN working becomes a factor they are more respected. There are various characters in the ASN work environment, some discuss personal matters in the workplace and there are also those who focus on discussing their work accompanied by responsibility and morale.

Work environment that requires work discipline and regular time so that it distinguishes from a flexible work situation in several workplaces of new employees who are not bound to work time. The test for ASN when facing a situation stressed by the work environment so that it requires good mental mastery as an apparatus that is ahead of tasks in the bureaucracy compared to the personal ego but must advance the interests of the organization.

\section{Values}

As a state civil apparatus holds the principle on the basis that is understood as Accountability, Public Ethics, and AntiCorruption. Therefore, of course, these basic values have different contexts in accordance with the basic values that are the parent, for example, the honest value that is in the value of accountability to be accountable internally and externally for its performance. Public ethics has more behavioral contexts that prioritize excellent service to the public, and honesty and transparency are the basic values of anti-corruption so that this encourages apparatus to have full awareness of their duties and responsibilities which must be based on honesty values. Ethics can be understood as a system of evaluating behavior and beliefs to determine appropriate actions to ensure the protection of individual rights, including ways of making decisions. The code of ethics is rules that regulate behavior in a special group, the point of view is only directed at matters of principle in the form of written provisions this can be an integrity pact signed by the ASN.

The basic values that must be possessed by the state civil apparatus serve as guidelines for behavior that must be carried out by ASN in Indonesia, which is very important to understand ASN is not limited to knowing about the guidelines but practices and implements work and social life as ASN. Through ethics, the values that are guided by promises to ourselves or to institutions or countries reflected in the actions of ASN to maintain the quality of employee performance in various fields which are the responsibility of the state civil apparatus must be carried out optimally in order to give satisfaction to the community. 


\section{Exemplary}

Exemplary aspects that can be a driving force for every ASN. Besides that, monitoring and evaluation are needed. Evaluation is an implementation of warrior values, which includes four aspects namely; aspects of leadership, aspects of government cultural groups, aspects of changes in mindset and aspects of implementation of noble values in carrying out tasks. Mental revolution is actually born of a commitment to revive existing values, namely integrity.

This value and principle certainly cannot be separated from the name obedience to the rules that apply. Therefore, people who have integrity will surely be honest people and apply justice. There are some employees who are role models in carrying out their duties and personality that should be exemplified by other employees. It is not easy to carry out everything we have signed in the promise of being faithful to honesty as well as mutual commitment.

The application of the integrity pact in Public Institutions is to ensure that all activities and decisions in public institutions are carried out transparently to all parties because the Integrity Pact can be used as one of the documents for internal supervision. Integrity Pact is a promise on paper to carry out duties and responsibilities in accordance with applicable regulations. The promise will not be meaningful if it is not accompanied by intention, faith and manifested in real action. earnest to conduct procurement activities transparently. Exemplary which is first owned by the head of the organization in order to transmit the spirit of his example to all employees within his institution.

\section{Ceremonies (rites and ritual)}

The chairman who served as Regional Inspector also stressed to all State Civil Apparatus to continue to improve discipline and performance because it became the benchmark for leadership of one of the steps taken, namely the flag ceremony every Monday as a step in stabilizing the nation's mentality through habituating the implementation of national values. This is intended to restore the dignity of a nation that is nationally disciplined, loving the country, having national character and insight based on Pancasila. The government has approved regional development planning or Development Planning Deliberation as a means to involve the community in regional development planning.

Various initiatives have also agreed on regional participation to increase the effectiveness of community participation, including by instituting Planning Consultation procedures. Development in Regional Regulations. development of greater involvement of the Regional People's Representative Council in the planning process and collaboration with civil society organizations. Basically, Development Planning Consultation is planning that functions Bottom Up Planning, because planning from under the community is a subject not a Development Object. While the program planning of the Regional Work Unit in Top Down Planning policy planning was made by the Regional Work Unit. Here the Regional Work Unit is the subject of the community service provider. Development Planning deliberation is an annual meeting organized by the government to agree on a Work Plan for Development of the budget year planned with reference to the medium-term development plan. The purpose of the deliberation is to agree on the proposal for the results of excavation of ideas.

\section{Network}

The main challenge faced by government agencies at present is the lack of communication between institutions which results in constraints on government strategic programs in facing challenges in the current development era. Seeing the current dynamics and problems of organizational governance at the ministerial and regional government levels are very diverse, one of which is the frequent overlap of authority and weak relations between state institutions so that strengthening the network requires good communication. Based on observations in the field, communication between institutions needs to be optimized to equalize perceptions related to the vision and mission of development contained in government programs. Non Structural Institutions are institutions that are formed to assist the task of regional governments in carrying out their duties, especially to respond to increasingly complex organizational needs. Demands for the implementation of good governance can be optimized by maximizing special functions that cannot be carried out intact by the regional government. institutions whose field of activity adapts to livelihoods, and not the profession of the majority of the people living in a place.

Non-governmental organizations are actually a community group that is conscious of the right to get public services to improve their welfare and be able to do it independently. Whereas based on existing legislation what is meant by non-governmental organizations (NGOs) are organizations or institutions formed by members of the Indonesian citizen community voluntarily on their own will and are interested and engaged in certain activities set by organizations or institutions, as manifestation of community participation in an effort to improve the standard of living and prosperity of the community, which focuses on self-service. In addition, the involvement of the private sector in providing assistance through Corporate Social Responsibility (CSR) is a network of collaboration in the future in developing the community's ability to be independent and empowered.

An innovative organization certainly has a work program that has different ways of implementing it. But every organization that has a clear vision works to build an innovative culture by starting the view that everything can be predicted in the future. This view starts from the leader of the organization which will then be absorbed in all divisions and individuals within the organization. Especially 
if accompanied by a sense of trust and hope that is the same as the vision, mission, and goals of the organization. Innovative culture means that in these organizations cultivate a mindset to learn to see the world in new ways.

Innovative culture is important for the survival of an organization that can be started from the attitude of the leader's openness to changes that arise both internally and externally [8]. The relationship between organizational culture and innovation has been carried out in various studies. The many cultural variables studied have produced fragmented cultural concepts for the innovation of an organization including exclusive characteristics with social culture [9]. Leadership and managerial practices require a basic structure to determine what culture must be implemented in order to innovate and assess certain types of culture are instruments of effective and efficient coordination [10].

Culture can be built and culture can be learned to help organizational leaders to interact with each other with their employees. When values and beliefs in different cultures, a number of employees will have problems with organizational adjustments. Organizational culture that is built to improve organizational performance can encourage the improvement of individual behavior in organizations to work effectively and efficiently [11]. The biggest challenge for every organization is the demand to be able to build and develop an organizational culture in accordance with the demands of the external environment, the trend of innovative culture is an effective and efficient work culture to improve its performance to meet organizational needs internally and externally.

\section{CONCLUSION}

A work environment that demands regular work discipline and time so that it distinguishes from a flexible work situation in several new employee workplaces, the basic values that must be possessed by the state civil apparatus are guidelines for behavior that must be carried out by ASN in Indonesia which is very important to understand ASN. The application of the integrity pact in Public Institutions is to ensure that all activities and decisions in public institutions are carried out transparently to all parties because the Integrity Pact can be used as one of the documents for internal supervision. Exemplary which is first owned by the head of the organization in order to transmit the spirit of his example to all employees in his institution. The ceremonies related to development are shown through the Development Planning Consultation as a means to involve the community in regional development planning. The problem found was the lack of communication between institutions which resulted in the obstruction of the government's strategic program so that network development needed to be improved in terms of communication. The biggest challenge for every organization is the demand to be able to build and develop an organizational culture in accordance with the demands of the external environment.

\section{REFERENCES}

1. Collins, J. C., \& Porras, J. I. (1991). Organizational vision and visionary organizations. California management review, 34(1), 3052.

2. Sun, L. Y., Aryee, S., \& Law, K. S. (2007). High-performance human resource practices, citizenship behavior, and organizational performance: A relational perspective. Academy of management Journal, 50(3), 558-577.

3. Haveman, H. A. (1993). Ghosts of managers past: Managerial succession and organizational mortality. Academy of Management Journal, 36(4), 864-881.

4. Wibowo. (2010). Budaya Organisasi. Jakarta: PT Raja Grafindo Persada.

5. Gunadi. (2006). Mengkaji Ulang Budaya Kerja, Edisi Ketiga, Penerbit Human Capital, Jakarta.

6. Koberg, C. S., Detienne, D. R., \& Heppard, K. A. (2003). An empirical test of environmental, organizational, and process factors affecting incremental and radical innovation. The Journal of High Technology Management Research, 14(1), 21-45.

7. McGann, J. G., \& Johnson, E. C. (2005). Comparative think tanks, politics and public policy. Edward Elgar Publishing.

8. Pérez-Bustamante, G. (1999). Knowledge management in agile innovative organisations. Journal of knowledge management, 3(1), 6-17.

9. Huffman, R. C., \& Hegarty, W. H. (1993). Top management influence on innovations: Effects of executive characteristics and social culture. Journal of management, 19(3), 549-574.

10. Büschgens, T., Bausch, A., \& Balkin, D. B. (2013). Organizational culture and innovation: A meta-analytic review. Journal of product innovation management, 30(4), 763-781.

11. Nahruddin, Z., \& Tambajong, H. (2017). The Behavior of Apparatus and Cultural Organization in Provision of Public Service in District Level. Scholars Journal of Arts, Humanities and Social Sciences, 5(7B):716-720. 